\title{
Estrogen replacement therapy and cardioprotection: mechanisms and controversies
}

\section{M.T.R. Subbiah}

\author{
Correspondence \\ M.T.R. Subbiah \\ Division of Endocrinology \\ Department of Internal M edicine \\ University of Cincinnati \\ 234 Bethesda Ave. \\ Cincinnati, OH 45267 \\ Fax: + 1-513-221-1891 \\ E-mail: Ravi.Subbiah@uc.edu \\ Presented at the XVI Annual Meeting \\ of the Federação de Sociedades de \\ Biologia Experimental, Caxambu, MG, \\ Brazil, August 29 - September 1 , \\ 2001. \\ Research supported by the \\ National Heart, Lung and \\ Blood Institute (No. HL-50881)
}

Division of Endocrinology, D epartment of Internal Medicine, University of Cincinnati Medical Center, Cincinnati, OH, USA

Abstract

Epidemiological and case-controlled studies suggest that estrogen replacement therapy might be beneficial in terms of primary prevention of coronary heart disease (CHD). This beneficial effect of estrogens was initially considered to be due to the reduction of low density lipoproteins (LDL) and to increases in high density lipoproteins (HDL). Recent studies have shown that estrogens protect against oxidative stress and decrease LDL oxidation. Estrogens have direct effects on the arterial tissue and modulate vascular reactivity through nitric oxide and prostaglandin synthesis. While many of the effects of estrogen on vascular tissue are believed to be mediated by estrogen receptors $\alpha$ and $\beta$, there is evidence for 'immediate non-genomic' effects. The role of HDL in interacting with $17 \beta$-estradiol including its esterification and transfer of esterified estrogens to LDL is beginning to be elucidated. Despite the suggested positive effects of estrogens, two recent placebo-controlled clinical trials in women with CHD did not detect any beneficial effects on overall coronary events with estrogen therapy. In fact, there was an increase in CHD events in some women. Mutations in thrombogenic genes (factor $\mathrm{V}$ Leiden, prothrombin mutation, etc.) in a subset of women may play a role in this unexpected finding. Thus, the cardioprotective effect of estrogens appears to be more complicated than originally thought and requires more research.

\section{Introduction}

Epidemiological studies have shown a $50 \%$ reduction in coronary heart disease (CHD) after estrogen replacement therapy (ERT) in postmenopausal women (1-2). This protective effect of estrogen is presumably due to its ability to favorably alter low/high density lipoprotein (LDL/HDL) ratios and decrease vascular reactivity and oxidative stress (3). Three major placebo-controlled trials designed to study whether ERT re-

\section{Key words}

- Estrogen therapy

- Postmenopausal women

- Cardiovascular disease

- Plasma lipoproteins

- Lipoprotein oxidation

- Estrogen receptors

- Thrombosis

- Nitric oxide synthesis duces CHD have questioned this protective effect of estrogen. The Heart and Estrogen/ Progestin Replacement Study (HERS) was the first placebo-controlled trial. HERS noted that ERT not only failed to reduce the overall rate of coronary events, but actually increased CHD in the first year with a $89 \%$ increase in thromboembolic events (4). In the Estrogen and Atherosclerosis (ERA) Trial (5) there was no decrease in coronary artery disease progression with ERT in postmenopausal women with at least one coronary artery 
stenosis. In the Women's Health Initiative Hormone Replacement Trial (WHI-HRT) which includes postmenopausal women with an intact uterus taking ERT plus progestin and those without a uterus taking only ERT $(6,7)$, a small increase in the number of myocardial infarctions, strokes and thromboembolism was noted in women taking active hormones compared to the placebo group. Along with HERS and ERA, WHIHRT was the third trial to suggest that ERT is not cardioprotective in postmenopausal women with CHD and may actually increase thromboembolism and CHD events. Several hypotheses have been advanced to explain these unexpected findings. The most widely accepted notion is that thrombosis may be limited to a subset of women on estrogen who may be increasingly susceptible to thrombosis because of confounding risk factors, i.e., genetic mutations (8-11) in thrombogenic factors (factor V Leiden, prothrombin and plasminogen activator inhibitor gene mutations). Premarin (a brand of conjugated equine estrogen mixture marketed by Wyeth/ Ayerst Labs, Radnor, PA, USA) is the estrogen used in all major clinical trials. To date, the exact composition of Premarin is not known. Recently, another brand of conjugated estrogen called Cenestin (containing 10 estrogens in a known composition marketed by Duramed Pharmaceuticals) has received approval for the treatment of menopausal symptoms (12). Despite these concerns about thrombosis, a significant portion of postmenopausal women in the United States continue to take ERT for relief of menopausal symptoms and potential benefits in terms of osteoporosis and cardiovascular diseases. In terms of cardioprotection, studies continue to document improvements in risk factors related to heart disease $(2,3,13)$. Some of these studies are discussed below.

\section{Estrogen and plasma lipids}

Considerable data are available that docu- ment an increase in HDL and a reduction of LDL cholesterol following estrogen therapy (14). Studies have clearly established that estrogen decreases total plasma cholesterol (15) and increases or maintains plasma triglyceride levels (15-17). With the addition of progestin, plasma total cholesterol, LDL cholesterol and triglyceride levels decrease (16-18). The addition of progestin, however, slightly blunts the increase in HDL levels (16-18). HDL2 levels are increased with estrogen, but changes in HDL3 have been inconsistent $(17,18)$. Estrogen with or without progestin significantly lowered plasma lipoprotein(a) levels (19).

\section{Estrogens as antioxidants}

Recent studies have documented that estrogens are potent antioxidants and decrease LDL oxidation in vitro and in vivo $(3,20)$. Although earlier studies have used pharmacological concentrations of estrogens to document antioxidant activity, recently it has been shown that $17 \beta$-estradiol is active even at physiological concentrations (21). Furthermore, the potency of catechol estrogens is far greater than that of parent estrogens (22). Studies on the mechanism of estrogen antioxidant effects have shown that estrogens strongly inhibit superoxide formation with minor effects on hydrogen peroxide and hydroxyl radical formation (23). While estrogens decrease lipid peroxidation and formation of reactive oxygen species (23), androgens and progestins increase oxidative stress parameters (24). Clinical studies on humans using E2-based preparations have clearly shown decreased LDL oxidation $(25,26)$, while other studies using conjugated estrogens have yielded conflicting results $(27,28)$. Whether these differences are due to different estrogen preparations or time frames is not clear at this time.

\section{Estrogen and vascular tone}

Currently, there is a strong interest in the 
role of estrogens in mediating vascular tone and response to vasoactive agents. Studies have documented that E2 can induce relaxation of coronary arteries, reverse acetylcholine-induced vasoconstriction and improve exercise-induced myocardial ischemia in women with coronary artery disease (2932). Collins et al. (33) showed that E2 decreases acetylcholine-induced coronary artery responses only in women, but not in men. These vasodilatory effects of estrogen are largely believed to be mediated by increased synthesis and release of nitric oxide, a potent relaxant of vascular smooth muscle (34). Short-term E2 treatment significantly increased plasma nitric oxide levels in postmenopausal women (35). Synthesis and release of nitric oxide in cultured endothelial cells are increased significantly by estrogens $(36,37)$ and inhibited by androgens (37). Some investigators have been able to demonstrate (38) increased expression of endothelial nitric oxide synthase in women treated with estrogens. The effects of estrogens on nitric oxide synthesis is believed to be manifested by rapid non-genomic (without changes in gene expression) effects $(38,39)$. Elucidation of this phenomenon has indicated that the non-genomic effects may still be modulated by estrogen receptors and the readers are referred to an excellent review of this topic by Mendelsohn and Karas (39).

\section{Other mechanisms of estrogen action}

Some of the other mechanisms responsible for estrogen-mediated cardioprotection include increases in vascular prostacyclin synthesis (40), inhibition of aortic smooth muscle cell proliferation (41) and decreases in hemostatic factors $(42,43)$ like fibrinogen and plasminogen activator inhibitor- 1 . The expression of vascular cell adhesion molecule, a chemotactic factor produced by endothelial cells that attracts monocytes (44), is also inhibited by estrogens (45) and stimulated by androgens and progestins (46). The readers are referred to a critical review by Farhat et al. (47) on some of these mechanisms.

\section{Role of estrogen receptors}

Recent research has provided a great deal of information on the mechanisms involved in the intracellular binding of estrogens to estrogen receptors ( $\alpha$ and $\beta$ ), translocation to the nucleus and the occurrence of genomic effects upon binding to estrogen response elements (48-50). However, the significance of these two receptors in the manifestation of the cardioprotective effect of estrogen is still open to question since mice lacking both of these receptors continue to demonstrate inhibition of intimal proliferation after vascular injury (51). The distribution of these receptors in vascular and other tissues and their interactions with estrogens and antiestrogens are beyond the scope of this article and have been covered in some excellent recent reviews (52). The carcinogenic effect of exogenous estrogens either by estrogen receptor activation and cell proliferation (53) or by DNA adduct formation by metabolites of catechol estrogens (54) in breast tissues has been of much concern in postmenopausal women. There is strong evidence suggesting that long-term estrogen use increases the risk for endometrial and breast cancer in women on estrogen therapy $(55,56)$. Consequently there is a lot of interest in developing "designer estrogens" that do not have adverse effects on breast and endometrium, yet retain their beneficial effects on the bone and cardiovascular system.

Recently discovered selective estrogen receptor modulators seem to have no estrogen agonistic effects on breast and endometrial tissue (57), but their long-term cardiovascular benefits are still being assessed. 


\section{Significance of differential delivery of estrogens}

Therefore, considerable attention has been focused on targeting estrogens to desired tissues (ex: vascular tissue or site of atherosclerosis, bone, etc.). Our laboratory has been interested in achieving differential effects of estrogens by differential delivery to cells. During studies exploring this possibility, we have shown (58) that a significant fraction of 173 -estradiol $(<10 \%)$ is associated with lipoproteins (predominantly with HDL), where it can be subsequently esterified and transferred to $\operatorname{LDL}(59,60)$. These steps also appear to be important in the manifestation of the antioxidant effect of estrogens (61). Interestingly, increasing hydrophobicity of the estrogen molecule (by esterification) increases its association with LDL $(61,62)$, providing an opportunity to target estrogen derivatives complexed with native or modified LDL to vascular tissues. Future research should be directed at targeting estrogens to specific tissues without undesirable side effects.

\section{Acknowledgments}

The author is indebted to many colleagues who contributed significantly to some of these studies.

\section{References}

1. Barrett-Connor E \& Grady D (1998). Hormone replacement therapy, heart disease and other considerations. Annual Review of Public Health, 19: 35-72.

2. Stampfer MJ \& Colditz GA (1991). Estrogen replacement therapy and coronary heart disease: a quantitative assessment of epidemiological evidence. Preventive Medicine, 20: 47-63.

3. Subbiah MTR (1998). Mechanisms of cardioprotection by estrogens. Proceedings of the Society for Experimental Biology and Medicine, 217: 23-29.

4. Hulley S, Grady D \& Bush T (1998). Heart and Estrogen/Progestin Replacement Study (HERS). Randomized trial of estrogen plus progestin for secondary prevention of coronary heart disease in postmenopausal women. J ournal of the American Medical Association, 280: 605612.

5. Herrington DM, Reboussin DM, Brosnihan KB, Sharp PC, Schumaker SA, Snyder TE, Furberg CD, Kowalchuk CJ , Stuckey TJ , Rogers W, Givens DH \& Waters D (2000). Effects of estrogen replacement on the progression of coronary artery atherosclerosis. New England J ournal of Medicine, 343: 522-529.

6. McGowan JA \& Pottern L (2000). Commentary on the Women's Health Initiative. Maturitas, 34: 109-112.

7. Design of the Women's Health Initiative clinical trial and observational study. The Women's Health Initiative Study Group (1998). Controlled Clinical Trials,
19: 61-109.

8. Glueck CJ, Wang P, Fontaine RN, Tracy T, Sieve-Smith L \& Lang J E (1999). Effect of exogenous estrogen on atherothrombotic vascular disease risk related to the presence or absence of the factor $\mathrm{V}$ Leiden mutation (resistance to activated protein C). American J ournal of Cardiology, 84: 549-554.

9. Glueck CJ , Wang P, Fontaine RN, SieveSmith L \& Lang J E (2001). Interaction of estrogen replacement therapy with the thrombophilic $20210 \mathrm{G} / \mathrm{A}$ prothrombin gene mutation for atherothrombotic vascular disease: a cross-sectional study of 275 hyperlipidemic women. Metabolism, 50: 360-365.

10. Psaty BM, Smith NL, Lemaitre RN, Vos HL, Heckbert SR, LaCoix E \& Rosendaal FR (2001). Hormone replacement therapy, prothrombotic mutations and the risk of incident non-fatal myocardial infarction in postmenopausal women. J ournal of the American Medical Association, 285: 906913.

11. Gardemann A, Lohre J, Katz N, Tillmans $H$, Hehrlein FW \& Haberbosch W (1999). The 4G/4G genotype of the plasminogen activator inhibitor $4 \mathrm{G} / 5 \mathrm{G}$ gene polymorphism is associated with coronary atherosclerosis in patients at high risk for the disease. Thrombosis and Haemostasis, 82: 1121-1126.

12. Stevens RE, Hanford C, Wasan S, Cusack SL \& Phelps KV (2000). A 12 week clinical trial determining the efficacy of synthetic conjugated estrogen $\mathrm{A}$ (SCE) in the treatment of vasomotor symptoms in African American and Caucasian postmenopausal women. International J ournal of Fertility and Women's Medicine, 45: 264-272.

13. Gerhard M \& Ganz P (1995). How do we explain the clinical benefits of estrogen? Circulation, 92: 5-8.

14. Paganini-Hill A, Dworsky R \& Krauss RM (1996). Hormone replacement therapy, hormone levels and lipoprotein cholesterol concentration in elderly women. American J ournal of Obstetrics and Gynecology, 174: 897-902.

15. Farish E, Spowart K, Barnes J F, Fletcher CD, Hart PM \& Degen MM (1996). Effects of postmenopausal hormone replacement therapy on lipoproteins including $\mathrm{Lp}(\mathrm{a})$ and LDL subfractions. Atherosclerosis, 126: 77-84.

16. Landenpara S, Puolakka J, Pyorola T, Luotola H \& Taskinen MR (1996). Effects of postmenopausal estrogen/progestin replacement therapy on LDL particles: comparison of transdermal and oral treatment regimens. Atherosclerosis, 122: 153-162.

17. Miller VT, Muessing RA, Larosa JC, Phillips EA \& Stilman RJ (1991). Effects of conjugated estrogen with and without three different progestins on lipoproteins, high density lipoprotein sub-fractions and apolipoprotein A1. Obstetrics and Gynecology, 77: 235-240.

18. Ottoson U, J ohansson B \& Von Schoultz $B$ (1985). Subfractions of high density cho- 
lesterol during estrogen replacement therapy: a comparison between progestogens and natural progesterone. American J ournal of Obstetrics and Gynecology, 151: 746-750.

19. Soma MR, Oswago I, Paoletti R, Fumagalli $R$, Morriset J D, Moschia M \& Crosignani $P$ (1993). The lowering of lipoprotein (a) induced by estrogen plus progesterone therapy in postmenopausal women. Archives of Internal Medicine, 153: 14021408.

20. Ayers S, Tang M \& Subbiah MTR (1996). Estradiol-17ß as an antioxidant: distinct features when compared to other fat soluble antioxidants. J ournal of Laboratory and Clinical Medicine, 128: 367-375.

21. Shwaery GT, Vita GA \& Keaney J r J F (1997). Antioxidant protection of LDL by physiological concentrations of 17ß-estradiol. Requirement for estradiol modification. Circulation, 95: 1378-1385.

22. Tang $M$, Abplanalp $W \&$ Subbiah MTR (1996). Superior and distinct antioxidant effect of selected estrogen metabolites on lipid peroxidation. Metabolism, 45: 411-414.

23. Ayers S, Abplanalp W, Liu J H \& Subbiah MTR (1998). Mechanisms involved in the protective effects of estradiol-17ß on lipid peroxidation and DNA damage. American J ournal of Physiology, 274: E1002-E1008.

24. Zhu X, Bonet B \& Knopp RH (1997). 17ßEstradiol, progesterone and testosterone inversely modulate low density lipoprotein oxidation and cytotoxicity in cultured placental trophoblast and macrophages. American J ournal of Obstetrics and Gynecology, 177: 196-209.

25. Sack MN, Rader DJ \& Cannon J r RO (1994). Oestrogen and inhibition of oxidation of low density lipoproteins in postmenopausal women. Lancet, 343: 269270.

26. Wilcox J G, Hwang J , Hodis HN, Sevanian A, Stanczyk FZ \& Lobo RA (1997). Cardioprotective effects of individual conjugated equine estrogens through their possible modulation of insulin resistance and LDL oxidation in postmenopausal women. Fertility and Sterility, 67: 57-62.

27. Guetta V, Lush RM, Figg WD, Waclawiw MA \& Cannon J r RO (1995). Effects of antiestrogen tamoxifen and conjugated estrogens on low density lipoprotein concentration and oxidation in postmenopausal women. J ournal of the American College of Cardiology, 76: 1072-1073.

28. McManus J , McEnany J , Thompson W \& Young IS (1997). The effect of hormone replacement therapy on the oxidation of low density lipoprotein in postmenopausal women. Atherosclerosis, 135: 7381.

29. J iang C, Sarrel PM, Poole-Wilson PA \& Collins P (1992). Acute effect of 17 beta estradiol on rabbit coronary artery contractile response to endothelin-1. American J ournal of Physiology, 263: H271$\mathrm{H} 275$.

30. Williams J K, Adams MR, Herrington DM $\&$ Clarkson TB (1992). Short term administration of estrogens and vascular response of atherosclerotic coronary arteries. J ournal of the American College of Cardiology, 20: 452-457.

31. Reis SE, Gloth ST, Blumenthal RS, Resar J R, Zacur HA, Gersenblith G \& Brinker J A (1994). Ethinyl estradiol acutely attenuates abnormal coronary vasomotor response to acetylcholine in postmenopausal women. Circulation, 89: 52-60.

32. Rosano GMC, Sarrell RM, Poole-Wilson PA \& Collins D (1993). Beneficial effect of estrogen on exercise induced myocardial ischemia in women with coronary artery disease. Lancet, 362: 133-136.

33. Collins $P$, Giuseppe MC, Rosano MC, Sarrell PM, Ulrich L, Adamopoulos S, Beale CM, McNeill J G \& Poole-Wilson A (1995). 17ß-Estradiol attenuates acetyl choline induced coronary arterial constriction in women but not men with coronary heart disease. Circulation, 92: 24-30.

34. Collins P, Shay J , J iang C \& M oss J (1994). Nitric oxide accounts for dose dependent estrogen mediated coronary relaxations after acute estrogen withdrawal. Circulation, 90: 1964-1968.

35. Cicinelli EC, Ignarro LJ, Schonauer LM, Matteo MG, Galantino P \& Balzano G (1998). Effects of short term transdermal estradiol administration on plasma levels of nitric oxide in postmenopausal women. Fertility and Sterility, 69: 58-61.

36. Hishikawa K, Nakaki T \& Marumo T (1995). Upregulation of nitric oxide synthase by estradiol in human endothelial cells. FEBS Letters, 360: 291-293.

37. Singh R, Pervin S, Shryne J, Gorski R \& Chaudhari G (2000). Castration increases and androgens decrease nitric oxide synthase activity in the brain: physiological implications. Proceedings of the National Academy of Sciences, USA, 97: 36723677.

38. Chen Z, Yuhanna IS, Galcheva-Gargova Z, Karas RH, Mendelsohn ME \& Shaul PW (1999). Estrogen receptor $\alpha$ mediates the non-genomic activation of endothelial nitric oxide synthase by estrogen. J ournal of Clinical Investigation, 103: 401-406.
39. Mendelsohn ME \& Karas RH (1999). The protective effects of estrogen on the cardiovascular system. New England J ournal of Medicine, 340: 1801-1811.

40. Fogelberg $M$, Vesterquist $O$, Diezfalusky U \& Henriksson P (1990). Experimental atherosclerosis: effect of estrogen and atherosclerosis on thromboxane and prostacyclin formation. European J ournal of Clinical Investigation, 20: 105-110.

41. Bhalla RC, Toth KF, Bhatty RA, Thompson LP \& Sharma RS (1997). Estrogen reduces proliferation and agonist induced calcium increase in coronary artery smooth muscle cells. American J ournal of Physiology, 272: H1996-H2003.

42. Saloma V, Rasi V \& Pekkanen J (1997). Association of hormone replacement therapy with hemostatic and other cardiovascular risk factors. The FINRISK Hemostasis Study. Arteriosclerosis, Thrombosis, and Vascular Biology, 15: 1549-1555.

43. Koh KK, Mincemoyer R \& Bui MN (1997). Effect of hormone replacement therapy on fibrinolysis in postmenopausal women. New England J ournal of Medicine, 336: 683-690.

44. Kume N, Cybulsky MI \& Gimbrone MA (1992). Lysophosphatidylcholine, a component of atherogenic lipoproteins, induces mononuclear leukocyte adhesion molecules in cultured human and rabbit arterial endothelial cells. J ournal of Clinical Investigation, 90: 1138-1144.

45. Caulin-Glazer T, Watson TA, Pardi R \& Bender J R (1996). Effects of estradiol on cytokine-induced endothelial cell adhesion molecule expression. J ournal of Clinical Investigation, 98: 36-42.

46. McCrohon J A, J essup W, Handelsman DJ $\&$ Celermajer DS (1999). Androgen exposure increases human monocyte adhesion to vascular endothelium and endothelial cell expression of vascular cell adhesion molecule. Circulation, 99: 2317 2322.

47. Farhat MY, Levigne MC \& Ramwell PW (1996). The vascular protective effect of estrogen. FASEB J ournal, 10: 615-624.

48. Pettersson K, Grandien K, Kuiper GJ M \& Gustafsson J A (1997). Mouse estrogen receptor beta forms estrogen response element-binding heterodimers with estrogen receptor alpha. M olecular Endocrinology, 11: 1486-1496.

49. Enmark E, Pelto-Huikko M, Grandien K, Fried G, Lagerkrantz S, Lagerkrantz J , Nordenskjold M \& Gustafsson J A (1997). Human estrogen receptor beta: gene structure, chromosomal localization and expression pattern. J ournal of Clinical En- 
docrinology and Metabolism, 82: 42584265.

50. Kuiper GJ M, Carlsson B, Grandien K, Enmark E, Haagblad J \& Gustafsson J A (1997). Comparison of the ligand binding specificities and transcript tissue distribution of estrogen receptors $\alpha$ and $ß$. Endocrinology, 138: 863-870.

51. Karas RH, Schulten H, Pare G, Aromovitz MJ , Ohlsson C, Gustafsson J A \& Mendelsohn ME (2001). Effect of estrogen on the vascular injury response in estrogen receptor alpha, beta (double) knockout mice. Circulation Research, 89: 534-539.

52. Nilsson $\mathrm{S}$, Makela $\mathrm{S}$, Trueter $\mathrm{E}$, Tujague M, Thomsen J , Andersson G, Enmark E, Pettersson K, Warner M \& Gustafsson J (2001). Mechanisms of estrogen action. Physiological Reviews, 81: 1536-1565.

53. Reed SE, Murthy MS, Kaufman M \& Scanlan EF (1996). Endocrine and paracrine hormones in the promotion, progression and reoccurrence of breast can- cer. British J ournal of Surgery, 83: 10371046.

54. Roy D \& Liehr J G (1999). Estrogen, DNA damage and mutations. Mutation Research, 424: 107-115.

55. Colditz GA (1996). Postmenopausal estrogen and breast cancer. J ournal of the Society for Gynecologic Investigation, 3: 5056.

56. Zumoff B (1993). Biological and endocrinological insights into the possible breast cancer risk from menopausal estrogen replacement therapy. Steroids, 58: 196-204.

57. Bryant HU \& Dere WH (1998). Selective estrogen receptor modulators: an alternative to estrogen replacement therapy. Proceedings of the Society for Experimental Biology and Medicine, 217: 45-52.

58. Tang $M$, Abplanalp $W \&$ Subbiah MTR (1997). Association of estrogens with human plasma lipoproteins: studies using estradiol-17ß and its hydrophobic derivative. J ournal of Laboratory and Clinical
Medicine, 129: 447-452.

59. Pahuja SL \& Hochberg RB (1994). A comparison of the esterification of steroids by rat lecithin: cholesterol acyl transferase and acyl coenzyme A:cholesterol transferase. Endocrinology, 136: 180-186.

60. Provost PR, Lavallee B \& Belanger A (1997). Transfer of dehydroepiandrosterone and pregnenolone-fatty acid esters between human lipoproteins. J ournal of Clinical Endocrinology and Metabolism, 82: 182-187.

61. Abplanalp W, Ayers S, Scheiber M, Kessel B, Liu J \& Subbiah MTR (2000). Potential role of $\mathrm{HDL}$ in the manifestation of antioxidant effect of estrogens on LDL peroxidation. European J ournal of Endocrinology, 142: 79-83.

62. Abplanalp W \& Subbiah MTR (2001). Uptake and protection against oxidative stress by estrogen esters in THP-1 human macrophage cell lines. Gynecologic and Obstetric Investigation, 51: 81-84. 